\title{
BNFL and Nirex in deep water over nuclear waste disposal plans
}

\section{London}

Proposals by British Nuclear Fuels Ltd (BNFL) to bury intermediate-level waste deep under the Irish Sea near Sellafield have incensed the Irish government and undermined plans by the British radioactive waste agency Nirex.

BNFL made the surprise announcement of its investigations into deep-sea dumping as part of a press release on its plans to spend $£ 20$ million to improve its low-level nuclear waste disposal site at Drigg. Conceptual plans call for a repository $800 \mathrm{~m}$ below the seabed, half a kilometre offshore.

This is an embarrassment for Nirex, which is responsible for the development and operation of low and intermediate level waste facilities. It had just announced that public consultation would be sought on possible burial methods for nuclear waste through a consultative document to be published in November.

The Nirex move is perceived as a way to overcome public criticism and the socalled Nimby (not in my back yard) syndrome, as well as accusations that the government's nuclear waste disposal policy has been in a state of confusion ever since the pre-election abandonment of four potential shallow waste disposal sites in marginal Conservative seats.

Although Nirex is responsible for nuclear waste disposal, BNFL, which has a 40 per cent share and directors on the board of Nirex, apparently developed its plans without consulting the rest of the industry.

Deep burial in the seabed close to Sellafield is seen by BNFL as preferable to transporting the waste. Sellafield, which reprocesses nuclear fuel from several

\section{Hepavax B: correction}

AN article in Nature of 3 September $\mathbf{3 2 9}, 6$; 1987) stated that "Hepatitis vaccine contract goes to untested product". In fact, Hepavax B received extensive testing by both the Indonesian and the Korean regulatory authorities before being licensed. The statement was also made that "the Korean vaccine does not yet have the WHO [World Health Organization] seal of approval". It should be made clear that the World Health Organization is not a regulatory body, although it offers advice on occasion on whether a vaccine has been produced according to its guidelines. WHO has received no enquiry on this matter from the Korean or Indonesian authorities and no advice on Hepavax B has been given.

The article also that that it was unorthodox of the International Task Force on Hepatitis B to declare all vaccines acceptable if approved by the national regulatory authority. In fact, a country will frequently accept a vaccine based upon licensing in the vaccine's country of origin without additional analysis by their own regulatory agencies.
European countries and Japan as well as Britain, produces two-thirds of Britain's intermediate-level nuclear waste. An estimated $180,000 \mathrm{~m}^{3}$ of intermediatelevel waste will require disposal by 2030 , and that would increase if the government dismantles its ageing Magnox reactors.

In contrast to the strident public opposition to Nirex's plans for shallow disposal, BNFL is not expecting much local opposition in Sellafield, where many residents are employed in the industry. But Ireland has pledged to put pressure on the British government to veto the seabed plan.

Nirex has already called for pre-bids from companies interested in designing and building a deep depository. The agency's consultative document will call for public submissions on three options: a deep bore-hole on the mainland with horizontal shaft connecting to disposal galleries under the sea; a shallow rail tunnel leading to undersea disposal galleries; or offshore boreholes deep into the seabed.

Kathy Johnston

\section{Medical research on the block \\ London}

In the continuing campaign to persuade the government to reverse its declining investment in scientific research, the heads of Britain's universities last week sought to focus attention on the mounting pressures facing clinical academic medicine.

At a meeting attended by the higher education minister, Robert Jackson, the Committee of Vice-Chancellors and Principals (CVCP) warned that falling numbers of university-funded clinical academic staff and increasing dependence on non-government-funded research contracts is causing "extreme concern" within the medical community. Between 1981 and 1986, the number of full-time clinical academic staff funded wholly from university sources fell by 13.4 per cent to 2,176. During the same period, the number of clinical academic staff funded from other sources, increased by 91 per cent to 1,668 . While the government sees this as a vindication of its insistence that more money is available from the private sector, academics are becoming increasingly worried about the implications.

According to CVCP chairman Sir Mark Richmond, the pressure on univeristies to seek 'soft money' for short-term research contracts is a severe strain on the existing state-funded research base, as well as favouring selected areas of research to the exclusion of less commercially attractive projects.
Chernobyl takes macaroni off Japan's menu

Tokyo

A JAPANESE consumer cooperative has stopped supplying imported Italian pasta to its customers in the wake of Chernobyl. The case illustrates the sensitivity of some Japanese to radioactivity.

The 147,000-member Seikatsu Kurabu ("Life Club") has set what must be one of the world's strictest standards for the maximum combined levels of caesium-134 and caesium-137 in food: $37 \mathrm{~Bq} \mathrm{~kg}^{-1}$, more than an order of magnitude smaller than the European Commission's limit $(600 \mathrm{Bc}$ $\mathrm{kg}^{-1}$ ), which some consider too severe.

The club set the level at one tenth of that adopted by Japan's Ministry of Health and Welfare because many of their members are women in their 20 s and 30 s who are pregnant or have infants and they have expressed fears about consuming contaminated food following the disclosure earlier this year that some foods imported from Europe (hazelnuts, spices, tea, cattle tripe and reindeer meat) have contained high caesium levels (several hundred to a few thousand $\mathrm{Bq} \mathrm{kg}^{-1}$ ) thought to be derived from Chernobyl fallout

Italian spaghetti with $80 \mathrm{~Bq} \mathrm{~kg}{ }^{-1}$ was detected by members of the club in February and the club slapped a general ban on imported spaghetti and macaroni in March. The club's restrictions are not confined to imported products. Some batches of tea leaves from Mie Prefecture were found to have about 40 to $50 \mathrm{~Bq} \mathrm{~kg}^{-1}$ of caesium. And 7.6 tons, or 15 per cent of the 1986 harvest, was burned at a loss of $¥$ 20 million $(\$ 140,000)$.

The club's members, however, would have to be real pasta gluttons or tea addicts to exceed the natural levels of radiation to which human beings are subjected (about 200 rem per year) by consuming these products. For example, at 60 $\mathrm{Bq} \mathrm{kg}^{-1}$, one would have to eat a few tons of spaghetti in a year - a daunting prospect.

David Swinbanks

- European Community member states are still wrangling over new radioactivity limits for foodstuffs to be imposed once the post-Chernobyl emergency limits expire at the end of October. Britain, France and Spain favour the caesium limits proposed by the Article 31 committee of Euratom of $4,000 \mathrm{~Bq} \mathrm{~kg}^{-1}$ for dairy products and 5,000 for other foods. West Germany wants to see the present limits maintained: 370 for dairy products and 600 for other foods. The European Commission proposes a compromise of 1,000 for dairy products and 1,250 for other foodstuffs.

Kathy Johnston 